\title{
GROWTH RESPONSES OF AILANTHUS ALTISSIMA SEEDLINGS TO $\mathrm{SO}_{2}$
}

\author{
P. E. Marshall \& G. R. Furnier $\dagger$ \\ School of Natural Resources, University of Michigan. \\ Ann Arbor, Michigan 48109, USA
}

\begin{abstract}
Growth of Ailanthus altissima (Mill.) Swingle seedlings exposed to various levels of sulphur dioxide $\left(\mathrm{SO}_{2}\right)$ was observed. Exposure for 1 or 2 weeks at $260 \mu \mathrm{g} \mathrm{m}^{-3}$ $(0.1 \mathrm{ppm})$ or $520 \mu \mathrm{g} \mathrm{m} \mathrm{m}^{-3}(0 \cdot 2 \mathrm{ppm})$ of $\mathrm{SO}_{2}$ significantly $(p \leq 0 \cdot 05)$ reduced extension growth and biomass accumulation of 2-and 3-week-old seedlings. Root growth was inhibited more than shoot growth, and reduction of growth was more severe at the higher $\mathrm{SO}_{2}$ concentration.
\end{abstract}

\section{INTRODUCTION}

The establishment and survival of recently germinated tree seedlings is severely limited by a number of environmental factors (Kozlowski, 1979). In this study the effects of one such factor, atmospheric $\mathrm{SO}_{2}$ pollution, on growth of Ailanthus altissima (Mill.) Swingle seedlings were investigated. Ailanthus, a tree native to Asia and first planted in North America in the late 1700s, frequently out-competes native vegetation. Its success is particularly evident in urban environments and is due, in part, to a lack of natural enemies, rapid growth rates, and very large reproductive capacity. In addition, ailanthus has been described as being able to flourish in poor, hard-packed soils and in smoky atmospheres (Illick \& Brouse, 1926; Vines, 1960; Harlow \& Harrar, 1968). However, little evidence has been presented to show that ailanthus is really resistant to air pollutants (Ranft \& Dässler, 1970).

Very few studies have examined the effects of $\mathrm{SO}_{2}$ on recently germinated woody plants (Berry, 1971, 1974; Constantinadou et al., 1976; Suwannapinunt \&

† Present address: Department of Forest Science, Oregon State University, Corvallis, Oregon 97331 , USA. 
Kozlowski, 1980). We felt it was important to learn more about the effects of physiological stresses on very young seedlings since previous studies have indicated that epigeously germinating woody plants may be very susceptible to stresses during the cotyledon stage of growth (Marshall \& Kozlowski, 1974, 1976). With these considerations in mind, we conducted this study to determine the effect of two relatively low concentrations of $\mathrm{SO}_{2}$ on growth of recently germinated ailanthus seedlings.

\section{METHODS}

Ailanthus seeds were collected in southeastern Michigan in the fall of 1977. Unstratified seeds were germinated in moist vermiculite on a greenhouse bench. When seedlings were about $2 \mathrm{~cm}$ tall (14-18 days after sowing and 5-7 days after radicle emergence), four seedlings were transplanted into each of 36 cylindrical plastic pots $(600 \mathrm{ml})$ containing loam, sand, and perlite $(2: 1: 1 \mathrm{v} / \mathrm{v})$. Twelve pots were placed in each of three identical growth chambers which were maintained as follows: $25^{\circ} \mathrm{C}$ days, $20^{\circ} \mathrm{C}$ nights, $70-80 \% \mathrm{RH}$, and a 16-h photoperiod with fluorescent and incandescent lights providing about $320 \mu \mathrm{E} \mathrm{m}^{-2} \mathrm{~s}^{-1}$ at the tops of the seedlings. Chamber 1 received charcoal-filtered air (control), Chamber 2 was maintained at $260 \mu \mathrm{g} \mathrm{m}^{-3} \mathrm{SO}_{2}(0 \cdot 1 \mathrm{ppm})$, and Chamber 3 was maintained at $520 \mu \mathrm{g} \mathrm{m}^{-3} \mathrm{SO}_{2}$ $(0.2 \mathrm{ppm}) . \mathrm{SO}_{2}$ concentrations were monitored with a Beckman $906 \mathrm{~A}$ which was calibrated with a permeation tube. Plants were harvested after 1 or 2 weeks of exposure in the chambers. Great care was taken to maintain intact root systems during the harvest. Measurements included lengths and dry weights of roots and shoots. Equality of variances among treatments was not a valid assumption, so data were analysed with a median test (Dixon \& Massey, 1969).

\section{RESULTS}

After 1 week of exposure to the treatments no visible injury was apparent and shoot elongation was not affected. However, root elongation was significantly inhibited by exposure to either $\mathrm{SO}_{2}$ concentration (Table 1). $\mathrm{SO}_{2}$ had no apparent effect on root biomass accumulation after 1 week, but it caused a significant reduction in shoot biomass (Table 1).

After 2 weeks, plants exposed to the lower $\mathrm{SO}_{2}$ concentrations were not significantly different from controls with respect to root and shoot lengths or root biomass, though shoot biomass accumulation was decreased (Table 1). Two weeks of exposure to the higher $\mathrm{SO}_{2}$ concentration caused some foliar yellowing and severe reductions of all growth parameters (root length- $58 \%$ of controls, shoot length$79 \%$ of controls, root dry weight $-58 \%$ of controls, and shoot dry weight $-77 \%$ of controls, Table 1). 
TABLE 1

EFFECTS OF $\mathrm{SO}_{2}$ ON AILANTHUS SEEDLING GROWTH

\begin{tabular}{|c|c|c|c|c|c|}
\hline Condition & $\begin{array}{c}\text { Exposure } \\
(\text { days })\end{array}$ & $\begin{array}{l}\text { Root length }{ }^{a} \\
(\mathrm{~cm})\end{array}$ & $\begin{array}{l}\text { Shoot length } \\
(\mathrm{cm})\end{array}$ & $\begin{array}{c}\text { Root dry wt } \\
\left(\text { mg seedling }^{-1}\right)\end{array}$ & $\begin{array}{l}\text { Shoot dry wt } \\
(\text { mg seedling }\end{array}$ \\
\hline \multirow[t]{2}{*}{ Control } & 7 & $9 \cdot 3($ & $9 \cdot 6)$ & $4.4(0.7)$ & $14.9(1.6)$ \\
\hline & 14 & $12.8 i$ & $5.7(0$ & 12.9 & $(4 \cdot 2)$ \\
\hline \multirow[t]{2}{*}{$260 \mu \mathrm{g} \mathrm{m}^{-3} \mathrm{SO}_{2}$} & 7 & $7.8(0 \cdot 8)^{*}$ & $4.9(0 \cdot 7)$ & $4.5(0.8)$ & $10.7(1.2)^{*}$ \\
\hline & 14 & $11.4(1.1)$ & $5 \cdot 6(0 \cdot 6)$ & $15 \cdot 0(2.2)$ & $32 \cdot 7(4.0)$ \\
\hline \multirow{2}{*}{$520 \mu \mathrm{g} \mathrm{m}^{-3} \mathrm{SO}_{2}$} & 7 & $6.8(0.9)^{*}$ & $4.8(0.8)$ & $5 \cdot 3(0 \cdot 6)$ & $11.4(1.2)^{*}$ \\
\hline & 14 & $7 \cdot 9(1 \cdot 1)^{*}$ & $4.8(0.6)^{*}$ & $7 \cdot 5(2 \cdot 4)^{*}$ & $15 \cdot 7(2 \cdot 8)^{*}$ \\
\hline
\end{tabular}

${ }^{a}$ Numbers are means with standard deviations in parentheses.

* Indicates that number is significantly different from that of the control $(p \leq 0.05)$.

Relative growth rates (RGR) were calculated from whole-plant biomass data to give an indication of the increase in plant weight per unit of original plant weight over a 1-week interval. Results show that the lower $\mathrm{SO}_{2}$ concentration $\left(260 \mu \mathrm{g} \mathrm{m}^{-3}\right)$ had no effect on RGR whereas the higher concentration had a severe effect (reduced the RGR to $29 \%$ of the control (Table 2)).

TABLE 2

RELATIVE GROWTH RATES OF AILANTHUS EXPOSED TO $\mathrm{SO}_{2}$ FOR 14 DAYS

\begin{tabular}{lc}
\hline \multicolumn{1}{c}{ Condition } & Relative growth rate \\
\hline Control & $0 \cdot 1652$ \\
$260 \mu \mathrm{g} \mathrm{m}^{-3} \mathrm{SO}_{2}$ & $0 \cdot 1632$ \\
$520 \mu \mathrm{g} \mathrm{m}^{-3} \mathrm{SO}_{2}$ & 0.0472 \\
\hline & \\
${ }^{a} \mathrm{RGR}=\frac{\ln \left(W_{2}\right)-\ln \left(W_{1}\right)}{t_{2}-t_{1}}$ & \\
where $W=$ weight in $\mathrm{mg}$. and $t=$ time in weeks.
\end{tabular}

\section{DISCUSSION}

Chronic exposure of very small ailanthus seedlings to moderate concentrations of $\mathrm{SO}_{2}$ appeared to inhibit root growth more than shoot growth. Suwannapinunt \& Kozlowski (1980) reported similar results with very young black locust and American elm seedlings, but they had used much higher $\mathrm{SO}_{2}$ concentrations and much shorter exposure times. The reduction of root growth in very young woody seedlings could have serious implications in seedling establishment and early seedling growth since inhibited root growth could limit water uptake.

Others have reported that brief exposures to high $\mathrm{SO}_{2}$ concentrations can also increase transpirational water losses from foliage of young woody seedlings (Suwannapinunt $\&$ Kozlowski, 1980). Sulphur dioxide pollution appears to increase woody seedlings' susceptibility to drought stress which, for very young seedlings, 
can greatly impair seedling development and growth and may be responsible for considerable seedling mortality (Kozlowski, 1979). Impaired root growth could also affect mineral nutrient relations and growth regulator balances in small seedlings.

Growth reductions in woody angiosperms following chronic exposures to moderate concentrations of $\mathrm{SO}_{2}$ have been reported by many (Katz et al., 1939; Dochinger \& Jensen, 1975; Jensen \& Dochinger, 1979), but few studies have included recently germinated seedlings. Growth reductions in response to $\mathrm{SO}_{2}$ in very young conifers have been reported (Berry, 1971, 1974; Constantinadou et al., 1976) but these have involved acute exposures to relatively high concentrations.

Growth reductions caused by $\mathrm{SO}_{2}$ have generally been attributed to decreased photosynthesis (Bennett \& Hill, 1974; Mudd, 1975; Barton et al., 1980). If photosynthesis was decreased in the fumigated ailanthus seedlings then one might expect root growth to be more inhibited than shoot growth since shoots of small woody angiosperm seedlings are strong carbohydrate sinks (Marshall \& Kozlowski, 1974) and may outcompete roots for current photosynthates.

Photosynthesis impacts may be more serious for species with epigeal germination, that is, with cotyledons exposed above ground. Previous study has shown that small seedling development is closely linked to cotyledon photosynthesis (Marshall \& Kozlowski, 1976). Species with large cotyledons kept below ground (hypogeal germination) generally have rapid root elongation that is somewhat independent of current photosynthesis; thus such species may be more resistant to $\mathrm{SO}_{2}$-induced damage in very early stages of growth.

We have concluded from this study that during the first 3 weeks after emergence, ailanthus seedlings are not particularly resistant to chronic $\mathrm{SO}_{2}$ exposure with respect to growth inhibition. Such seedlings may become more or less tolerant of $\mathrm{SO}_{2}$ as they become older, but small seedling susceptibility to $\mathrm{SO}_{2}$ may limit seedling establishment. Further work which links pollution-caused growth reductions in very small seedlings to susceptibility to other environmental stresses is needed.

ACKNOWLEDGEMENTS

We wish to thank Dr K. F. Jensen of the USDA Forest Service for his helpful suggestions and for the use of equipment. The University of Michigan's Matthaei Botanical Gardens kindly provided technical assistance.

\section{REFERENCES}

Barton, J. R., Mclaughlin, S. B. \& McCanathy, R. K. (1980). The effects of $\mathrm{SO}_{2}$ on components of leaf resistance to gas exchange. Environ. Pollut. A, 21, 255-65.

BENNETT, J. H. \& HiLl, A. C. (1974). Acute inhibition of apparent photosynthesis by phytotoxic air pollutants. In Air pollution effects on plant growth, 115-27. ACS Symposium Series No. 3. 
BERRY, C.R. (1971). Relative sensitivity of red, jack, and white pine seedlings to ozone and sulfur dioxide. Phytopathology, 61, 231-2.

BERRY, C. R. (1974). Age of pine seedlings with primary needles affects sensitivity to ozone and sulfur dioxide. Phytopathology, 64, 207-9.

Constantinadou, H., Kozlowski, T. T. \& Jensen, K. F. (1976). Effects of sulfur dioxide on Pinus resinosa seedlings in the cotyledon stage. J. environ. Qual., 5, 141-4.

Dixon, W. J. \& MASSEY, F. J., JR. (1969). Introduction to statistical analysis. New York, McCraw-Hill.

DOCHINGER, L. S. \& JENSEN, K. F. (1975). Effects of chronic and acute exposure to sulphur dioxide on the growth of hybrid poplar cuttings. Environ. Pollut., 9, 219-29.

Harlow, W. M. \& Harrar, E. S. (1968). Textbook of dendrology. New York, McGraw-Hill.

Illick, J. S. \& Brouse, E. F. (1926). The Ailanthus tree in Pennsylvania. Bull. Pa. Dep. Forests Wat., No. 38 .

JENSEN, K. F. \& DoChinger, L. S. (1979). Growth responses of woody species to long- and short-term fumigation with sulfur dioxide. Res. Pap. N.E. For. exp. Sta. (US), NE-22.

Katz, M., Ledingham, G. A. \& McCallum, A. W. (1939). Symptoms of injury on forests and crop plants. In Effects of sulfur dioxide on vegetation, 51-103. Nat. Res. Counc. of Canada NRC No. 815.

KozLowsKi, T. T. (1979). Tree growth and environmental stress. Seattle, University of Washington Press.

MARShal. , P. E. \& Kozlowski, T. T. (1974). Photosynthetic activity of cotyledons and foliage leaves of young angiosperm seedlings. Can. J. Bot., 52, 2023-32.

Marshall, P. E. \& KozlowsKI, T. T. (1976). Importance of photosynthetic cotyledons for early growth of woody angiosperms. Physiologia Pl., 37, 336-40.

MudD, J. B. (1975). Sulfur dioxide. In Responses of plants to air pollution, 9-22. New York, Academic Press.

Ranft, H. \& Dässler, H. G. (1970). Smoke-hardiness test carried out on woods in an $\mathrm{SO}_{2}$ chamber. Flora, Jena, 159, 573-88. (In German.)

SuwanNaPinunt, W. \& Kozlowski, T. T. (1980). Effect of $\mathrm{SO}_{2}$ on transpiration, chlorophyll content, growth, and injury in young seedlings of woody angiosperms. Can. J. For. Res., 10, 78-81.

Vines, R. A. (1960). Trees, shrubs and woody vines of the southwest. Austin, University of Texas Press. 